\title{
Significance of metalloproteinases in the progression of the periodontal disease
}

Flávio Roberto Guerra Seabra ${ }^{\mathrm{a}}$, Rodrigo Gadelha Vasconcelos ${ }^{\mathrm{b}}$, Fernando José de Oliveira Nóbrega ${ }^{\mathrm{b}}$, Éricka Janine Dantas da Silveira ${ }^{\mathrm{C}}$, Lélia Maria Guedes Queiroz ${ }^{\mathrm{C}}$

\begin{abstract}
Objectives: The objective of this study was to evaluate the immunohistochemical expression of matrix metalloproteinases (MMPs) $-1,-2$ and -9 in the progression of the periodontal disease.

Materials and methods: Thirteen gingival biopsies with clinical diagnosis of gingivitis and 13 with periodontitis were obtained and processed by immunohistochemical method. Staining of MMPs was scored according to intensity, both in epithelium and in connective tissue, in absent staining $(-)$ which was attributed the score 0 ; weak staining $(+)$, score 1 ; and strong staining $(++)$, score 2 .

Results: MMP-1 has expressed significantly more than the others MMPs in gingivitis both in the epithelium ( $p=0.0008)$ and connective tissue $(p=0.0049)$. In periodontitis, both MMP-1 and MMP-9 has expressed significantly in the epithelium $(p<0,0001)$ and in the connective tissue $(p=0.0002)$. MMP-1 and MMP-9 presented more expression in periodontitis than in gingivitis but, MMP-1 only in connective tissue $(p=0,03)$ and MMP-9 in the epithelium $(p=0.003)$ and in the connective tissue $(p=0.04)$.

Conclusion: These results indicate MMP-1 have an important role in connective tissue degradation and bone loss and MMP-9, that has expressed more in periodontitis, may have some role in the progression of gingivitis to periodontitis by acting in bone resorption.
\end{abstract}

Key words: Periodontal disease, Inflammation, Matrix metalloproteinases, Immunohistochemistry.

\section{Significado das metaloproteinases na progressão da doença periodontal}

\section{Resumo}

Objetivos: avaliar a expressão imunohistoquímica das metaloproteinases da matriz (MMP) $-1,-2$ e -9 na progressão da doença periodontal.

Materiais e métodos: treze biópsias gengivais com diagnóstico clínico de gengivite e 13 com periodontite foram processadas pelo método de imunohistoquímica. A marcação das MMPs foi feita de acordo com a intensidade, tanto no epitélio quanto no tecido conjuntivo, em: ausente (-), que foi atribuída a pontuação 0; fraca $(+)$, pontuação 1 ; e marcação forte $(++)$, pontuação 2 .

Resultados: na gengivite, a MMP-1 foi significativamente mais expressa do que as outras MMPs, tanto no epitélio $(p=0,0008)$ como no tecido conjuntivo $(p=0,0049)$. Na periodontite, tanto a MMP-1 quanto a MMP-9 foram significativamente expressas no epitélio $(p<0,0001)$ e no tecido conjuntivo $(p=0,0002)$. MMP-1 e MMP9 apresentaram maior expressão na periodontite do que na gengivite, sendo a MMP-1 no tecido conjuntivo $(p=0,03)$ e MMP-9 no epitélio $(p=0,003)$ e no tecido conjuntivo $(p=0,04)$.

Conclusão: Os resultados indicam que a MMP-1 tem papel importante na degradação do tecido conjuntivo e na perda óssea e a MMP-9, que foi mais expressa em periodontite, pode ter algum papel na progressão da gengivite para periodontite, atuando na reabsorção óssea.

Palavras-chave: doença periodontal, inflamação, metaloproteinases da matriz, imunohistoquímica. a Potiguar University (UnP), Natal-RN, Brazil

b PhD candidate Post Graduate Program in Oral Pathology, Federal University of Rio Grande do Norte (UFRN), Natal-RN, Brazil

${ }^{c}$ Oral Pathology Post Graduate Program, Federal University of Rio Grande do Norte (UFRN), NatalRN, Brazil 


\section{Introduction}

Periodontal diseases represent a group of lesions affecting human dentition, which might result in the loss of teeth. The diagnosis is traditionally based on clinical parameters and indices that reflect a history of periodontal diseases but cannot predict future disease activity [1]. Extensive modifications result from an unbalanced immune response against infectious agents in the microbial dental plaque. In this process the production and activation of a group of enzymes named matrix metalloproteinases (MMPs) can be recognized, which are able to increase tissue remodeling, in addition to other non-specific proteases, various chemokines and nitric oxide $[1,2]$.

The MMPs are a family of at least 20 proteolitic enzymes that have function of degrading extracellular matrix of connective tissue both in physiologic or in pathologic processes. MMPs were implicated in several pathologic processes as rheumatoid arthritis, atherosclerosis, cancer invasion and metastasis [3]. Since collagenases were implicated in periodontal diseases, efforts have been made to understanding their role in tissue destruction observed in gingivitis and periodontitis [4]. MMP-1, MMP-8 and MMP-13 are the three types of Collagenases. MMP-1 (collagenase 1) is a $52 \mathrm{kDa}$ enzyme in its inactive form (pro-MMP-1) and $41 \mathrm{kDa}$ inactive form and can be expressed by keratinocytes, fibroblasts, chondrocytes, monocytes, machrofages and others. It can degrade collagen I, II, III, VII, VIII, X, XI, gelatin, entacin, fibronectin, laminin, tenacin and vitronectin.

MMP-2 and MMP-9 constitute the group of gelatinases $\mathrm{A}$ and $\mathrm{B}$, respectively. MMP-2 is $65 \mathrm{kDa}$ enzyme and MMP-9 is a $84 \mathrm{kDa}$ enzyme. Basically, the same function is attributed to these enzymes that can degrade collagens III, IV, V, VII and XI, as well as gelatin, elastin, fibronectin and laminin. Colagens IV, VII and laminin are the principal components of the basement membrane, so MMP-2 and MMP-9 are considered important in degradation of basement membrane in processes as angiogenesis and cancer invasion and metastasis $[3,5]$.

Some gingival microorganisms, such as Porphyromonas gingivalis and Actinobacillus actinomycetemcomitans, are capable of producing proteases that damage the host tissue, especially collagen fibers in gingival connective tissue. However, such microbial proteases were suggested to have a secondary participation in collagen degradation, which seems to depend mostly on enzymes produced by the host cells. The evidence of the importance of MMPs in periodontal destruction are consistent, and they have been supported by a number of studies [6,7].

As in periodontal disease, extensive disorganization of the extracellular matrix promotes the loss of adhesion between the teeth and periodontium, thus, the aim of the present study was to analysis the immunoexpression and distribution of MMP-1, -2 and -9 in human gingival biopsies of patients which were clinically diagnosed with gingivitis and periodontitis and verify the expression can indicate periodontal disease stage and if these enzymes participate of etiopathogenesis of this disease. The model of this study is new and relevant and may provide relevant information contributing to the use of antagonists of these proteins in the treatment of the periodontal disease.

\section{Materials and Methods}

Twenty-six gingival biopsies specimens were obtained from Pathologic Anatomy Service of Oral Pathology Discipline archives, Dentistry College of Federal University of Rio Grande do Norte, Brazil. The biopsies used in the study were from clinical cases where the treatment plan was necessary such as aesthetic surgical periodontal procedures, crown lengthening procedures and dental extractions and the patients were examined by an experienced periodontist. All sites in which the biopsies were accomplished had been diagnosed according to clinical and radiographic parameters as gingivitis (gingival inflammation without detectable bone loss) or Periodontitis (gingival inflammation with radiographically detectable bone loss), resulting in 13 specimens clinically diagnosed as Gingivitis and 13 with clinical diagnoses of Chronic Periodontitis. This research was designance in concordance with the guidelines issue by the Research Ethic Committee of Federal University of Rio Grande do Norte, Natal-RN, Brazil.

Immunohistochemistry was performed on paraffin sections of the 26 cases of periodontal disease mounted on glass slides. All surgical specimens were fixed in $10 \%$ neutralbuffered formalin ( $\mathrm{pH}$ 7.4) and then embedded in paraffin. Three- $\mu$ m-thick tissue sections were mounted on 3-aminopropyltrietoxi-silan-coated slides (Sigma Chemical CO., St. Louis, MO, USA) and then submitted to streptavidinbiotin technique (SABC) using primary antibodies antiMMP-1, anti-MMP-2 and anti-MMP-9. Briefly, the sections were dewaxed with xylene, and rehydrated in graded ethanol. Endogenous peroxidase activity was blocked by immersion of slides in $10 \mathrm{vol}$. hydrogen peroxide for $10 \mathrm{~min}$. The sections were then heated in citrate buffer $(\mathrm{pH}$ 6.0) three times for $10 \mathrm{~min}$ each in a microwave oven at $500 \mathrm{~W}$ to retrieve antigenicity. The sections were rinsed in distilled water, and then in TRIS-HCL). The sections were incubated with primary antibody against MMP-1 (mouse monoclonal anti-MMP-2, clone 36006.211, RD systems, diluted 1:40) overnight, against MMP-2 (mouse monoclonal antiMMP-3, clone 15W2, Novocastra, diluted 1:50) for $60 \mathrm{~min}$, and against MMP-9 (mouse monoclonal anti-MMP-9, clone 15W2, Novocastra, diluted 1:40) overnight. They were then rinsed in Tween 20 solution (1\%), after washing in TRIS-HCL, and incubation with streptavidin-biotin complex 1:100 for $20 \mathrm{~min}$ (DAKO A/S, Golstrup, Denmark) staining was developed with $0.03 \% 3$, 3-diaminobenzidinetetrahydrochloride in $100 \mathrm{ml}$ Tris-HCL ( $\mathrm{pH} 7.5)$ containing $0.6 \mathrm{ml} 20$ vol. Hydrogen peroxide for $3 \mathrm{~min}$ in dark chamber, and then lightly counterstained with Mayer's hematoxylin.

The negative control consisted of the replacement of the primary antibody for bovine serum albumin $(1 \%$ BSA - Bovine Serum Albumin) solution in buffer, and 
positive staining controls were performed with breast adenocarcinomas.

A single examiner blinded to the patient diagnosis determined the number of immunostained cells twice at different times. Staining of MMPs was scored according to intensity, both in epithelium and in connective tissue, in absent staining $(-)$ which was attributed, for statistical calculation, the score 0 ; weak staining $(+)$ which was attributed the score 1 ; and strong staining $(++)$ which was attributed the score 2 (Figures 1 and 2).
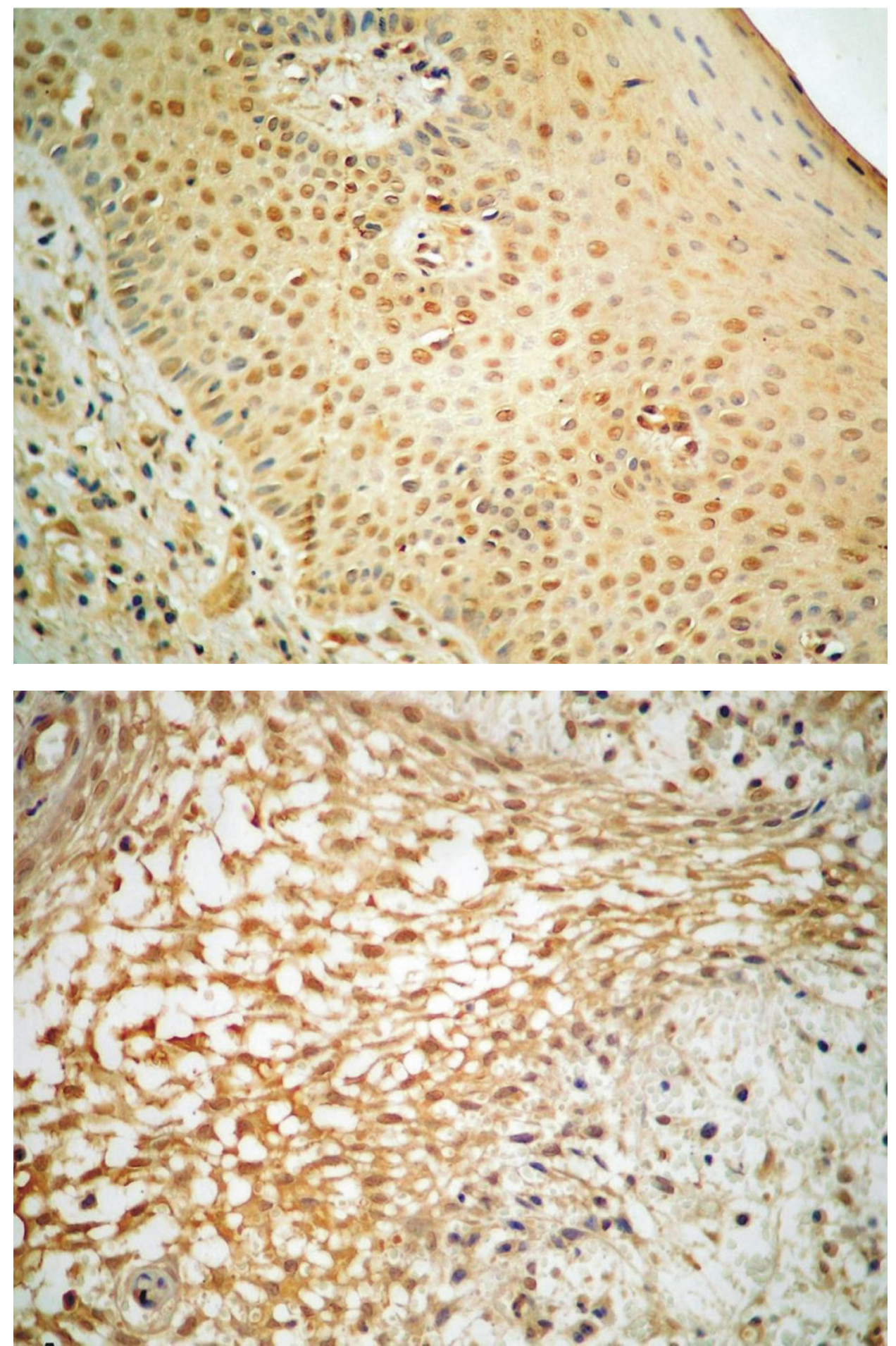

Fig. 1. A strong staining in epithelial gingival tissue for MMP-1 in periodontitis $(200 x)$
Fig. 2. Connective tissue strong staining for MMP-1 in gingival tissue for periodontitis, with evidence of stained fibroblasts and leucocytes (200x) 


\section{Results}

- Comparison between MMP-1, MMP-2 and MMP-9

As shown in Table 1, MMP-1 was significantly more expressed than the others, both in epithelium and into the connective tissue when the clinical/radiographic diagnosis was gingivitis. In periodontitis, shown in Table 2, MMP-1 and MMP-9 were considered more expressed than MMP-2 and these data resulted in significant statistical difference.

Table 1. Mean posts and statistical significance of immunohistochemical staining for MMP-1, MMP-2 e MMP-9 in Gingivitis.

\begin{tabular}{l|cccc}
\hline & MMP-1 & MMP-2 & MMP-9 & P-value \\
\hline Epithelium & $28.42 \mathrm{a}$ & $14,92 \mathrm{~b}$ & $16,65 \mathrm{~b}$ & $\mathbf{0 , 0 0 1 3}$ \\
Connective tissue & $27,19 \mathrm{a}$ & $15,84 \mathrm{~b}$ & $16,96 \mathrm{~b}$ & $\mathbf{0 , 0 0 9 3}$ \\
\hline
\end{tabular}

Different letters means significant statistical differences for $p=0,05$ according Kruskal-Wallis test and Dunn post-test.

Table 2. Mean posts and statistical significance of immunohistochemical staining for MMP-1, MMP-2 e MMP-9 in Periodontitis.

\begin{tabular}{l|c|c|c|c}
\hline & MMP-1 & MMP-2 & MMP-9 & P-value \\
\hline Epithelium & $28.00 \mathrm{a}$ & $8.15 \mathrm{~b}$ & $23.84 \mathrm{a}$ & $<0.0001$ \\
Connective tissue & $24.38 \mathrm{a}$ & $12.00 \mathrm{~b}$ & $23.61 \mathrm{a}$ & $\mathbf{0 . 0 0 3 3}$ \\
\hline
\end{tabular}

Different letters means significant statistical differences for $\mathrm{p}=0,05$ according Kruskal-Wallis test and Dunn post-test.

\section{- Comparison between Gingivitis and} Periodontitis in each Metalloproteinase

All cases of gingivitis and periodontitis had stained positively for MMP-1 in epithelium and in connective tissue. The epithelial tissue stained weakly in $30.8 \%$ and strongly $69.2 \%$ of analyzed gingivitis cases and in periodontitis weak expression was found in $7.7 \%$ while $92.3 \%$ showed strong positivity. In gingival connective tissue, $53.8 \%$ of gingivitis cases showed weak and $46.2 \%$ strong expression while in periodontitis cases $7.7 \%$ expressed weakly and $92.3 \%$ strongly. These data resulted in statistically significant difference in expression of MMP-1 in connective tissue between gingivitis and periodontitis (Table 3 ).

Table 3. Scores of the imunohistochemical staining for MMP-1 in epithelium and connective tissue.

\begin{tabular}{llcccc}
\hline \multirow{2}{*}{ Epithelium } & & - & + & ++ & P-value \\
\multirow{2}{*}{ Connective tissue } & Gingivitis & 0 & 4 & 9 & \multirow{0}{*}{0.3} \\
& Periodontitis & 0 & 1 & 12 & \\
& Gingivitis & 0 & 7 & 6 & \multirow{0}{*}{$\mathbf{0 . 0 3}^{*}$} \\
\cline { 2 - 6 } & Periodontitis & 0 & 1 & 12 & \\
\hline
\end{tabular}

* Statistical significant difference for $p=0,05$ for Chi-square test.

None of the 26 specimens stained strongly for MMP-2 in epithelium. In gingivitis, a weak staining appeared in $84.6 \%$ and absence of expression was observed in $15.4 \%$. The periodontitis weak staining was found in $76.9 \%$ and absence of expression in $23.1 \%$. In gingival connective tissue, the gingivitis cases stained strongly in $7.7 \%$ and weakly in $53.8 \%$. No expression was observed in $38.5 \%$. In periodontitis, there were not cases with strong expression, in $61.5 \%$ a weak expression was found and in $38.5 \%$ the expression was absent. These data resulted in absence of statistical significance for expression of MMP-2 in epithelium as well as in connective tissue between gingivitis and periodontitis (Table 4).

Table 4. Scores of the imunohistochemical staining for MMP-2 in epithelium and connective tissue.

\begin{tabular}{llccccc}
\hline \multirow{3}{*}{ Epithelium } & & - & + & ++ & P-value \\
\multirow{2}{*}{ Connective tissue } & Gingivitis & 2 & 11 & 0 & \\
& Periodontitis & 3 & 10 & 0 & 0,74 \\
& Gingivitis & 5 & 7 & 1 & \multirow{2}{*}{0,85} \\
\cline { 2 - 6 } & Periodontitis & 5 & 8 & 0 & \\
\hline
\end{tabular}

No statistical significant difference for $p=0,05$ for Chi-square test.

The analysis of MMP-9 in epithelium showed that, in gingivitis this metalloproteinase was absent in $30.8 \%$ of the analyzed cases, stained weakly in $46.2 \%$ and strongly in $23.1 \%$. In periodontitis, $23.1 \%$ presented weak and $76.0 \%$ strong expression. In connective tissue, MMP-9 in gingivitis as absent in $38.5 \%$ of cases, weak in $46.2 \%$ and strong in $15.4 \%$ while in periodontitis $15.4 \%$ had no expression, $30.8 \%$ had weak and $53.8 \%$ had strong expression. These data resulted in statistical significant difference in MMP-9 expression between gingivitis and periodontitis in epithelial tissue (Table 5).

Table 5. Scores of the imunohistochemical staining for MMP-9 in epithelium and connective tissue.

\begin{tabular}{llcccc}
\hline \multirow{3}{*}{ Epithelium } & & -- & + & ++ & P-value \\
& Gingivitis & 4 & 6 & 3 & \\
\multirow{2}{*}{ Connective tissue } & Periodontitis & 0 & 3 & 10 & 0,74 \\
& Gingivitis & 5 & 6 & 2 & \\
\cline { 2 - 5 } & Periodontitis & 2 & 4 & 7 & 0,85 \\
\hline
\end{tabular}

* Statistical significant difference for $p=0,05$ for Chi-square test.

\section{Discussion}

Our results indicate the involvement of MMPs studied in the early tissue modifications associated with periodontal disease. Increased expression of MMPs in disease periodontal tissues seems to be the consensus in the literature and is thought to account for the destruction of soft and mineralized tissues that result in some of the clinical sign of periodontal disease.

Periodontal disease is classically described as an inflammatory process located in gingival tissues, caused by bacterial biofilm on the dental surfaces that has the potential to progress into the support periodontal tissues, leading to bone loss [5]. 
In accordance to Bergmann and Dlinzer [8], interleukin$1 \beta$ is an important pro-inflammatory cytokine involved in a variety of immunological processes in the host's response. It is one of the most potent osteoclast-activating factors in the human organism. It believed to play an important role in periodontal tissue destruction. Indded, studies report increased concentrations of Il-1 $\beta$ in gingival crevicular fluid at sites with gingivitis or periodontitis. This interleukin is an important on liberation and metalloproteinases activation.

Matrix metalloproteinases are a class of proteolytic enzymes that can degrade all components of extracellular matrix of the connective tissues both in physiologic as well as in pathologic events [5], therefore, this class of enzymes is clearly implicated in the pathogenesis of periodontitis $[5,9,10]$.

MMP-1 is produced by stimulation the several bacteria or host factors implicated in periodontal disease as LPS, TNF $\alpha$ and IL-1 [9] and has the capacity of degrading collagen type I, that is the main constitutive structural protein of the gingival connective tissue, periodontal ligament and bone.

In the present study, MMP-1 was strongly found in epithelial and connective tissue of gingiva affected by periodontal disease, both in gingivitis and in periodontitis. These data is in agreement to previous works that have shown MMP-1 in inflamed pulps and in periodontal tissues of periodontitis patients [11].

The fact that MMP-1 presents high rates both in gingivitis and in periodontitis, without increasing of its expression, can lead to suggest that this enzyme is important in destructive processes that takes place in gingival tissues since the earliest phases of periodontal diseases, until the latest phases in which is already found bone loss [7]. Therefore, together with another collagenase, the MMP-8, MMP-1 may be considered one of the most important degradative enzymes of periodontal disease and has its source in epithelial and connective tissue cells.

MMP-2 and MMP-9 are capable to degrade the main structural proteins of the basement membranes, and that is why they are extremely implicated in cancer invasion and metastasis, invasiveness of certain benign neoplasms as ameloblastomas and in regulation of angiogenesis [8] In fact, they already were implicated in formation of periodontal pocket by degrading the basement membrane of junctional epithelium, allowing the downgrowth of this tissue. It was shown that they can also have its production stimulated by some red complex bacterias [12].

In the present research, MMP-2 and MMP-9 showed low expression in gingivitis compared to MMP-1. In periodontitis MMP-9, but not MMP-2, had its expression elevated to levels of MMP1, mainly in epithelium. This corroborates to the hypothesis that these enzymes, mainly MMP-9, has great importance in pocket formation or bone resorption in periodontits and its elevation may be implicated in progression from established lesion to advanced lesion, or from gingivitis to periodontitis.

\section{Conclusions}

MMP-1 have an important role in connective tissue degradation and bone loss and MMP-9, that has expressed more in periodontitis, may have some role in the progression of gingivitis to periodontitis by acting in bone resorption.

\section{References}

1. Kraft-Neumärker M, Lorenz K, Koch R, Hoffmann T, Mäntylä P, Sorsa $\mathrm{T}$, et al. Full-mouth profile of active MMP-8 in periodontitis patients. J Periodontal Res 2012; 47:121-28.

2. Gonçalves LDR, Oliveira G, Hurtado PA, Feitosa A, Takiya CM, Granjeiro $\mathrm{JM}$, et al. Expression of metalloproteinases and their tissue inhibitors in inflamed gingival biopsies. J Periodont Res 2008; 43:570-77.

3. Kubota Y, Ninomiya T, Oka S, Takenoshita Y, Shirasuna K. Interleukin-1及dependent regulation of matrix metalloproteinase-9 (MMP-9) secretion and activation in the epithelial cells of odontogenic jaw cysts. J Dent Res 2000:79:1423-30.

4. Garlet GP, Martins WJr, Fonseca BA, Ferreira BR, Silva JS. Matrix metalloproteinases, their physiological inhibitors and osteoclast factors are differentially regulated by the cytokine profile in human periodontal disease. J Clin Periodontol 2004;31:671-79.

5. Sorsa T, Tjäderhane L, Salo T. Matrix metalloproteinases in oral diseases Oral Dis 2004:10:311-18.

6. Lorencini M, Silva JAF, de la Hoz CLR, Carvalho HF, Stach-Machado DR Changes in MMPs and inflammatory cells in experimental gingivitis. Histo Histopathol 2009;24:157-66.

7. Loo WTY, Wang M, Jin LJ, Cheung MN, Li GR. Association of matrix metalloproteinase (MMP-1, MMP-3 and MMP-9) and cyclooxygenase-2 gene polymorphisms and their proteins with chronic periodontitis. Arch Oral Biol 2011;56:1081-90

8. Bergman A, Deinzer R. Daytime variations of interleukin-1 $\beta$ in gingival crevicular fluid. Eur J Oral Sci 2008;116:18-22.

9. De Souza AP, Trevilatto PC, Scarel-Caminaga RM, de Brito RB Jr, Barros SP, Line SR. Analysis of MMP-9 (C-1562T) and TIMP-2 (G-418C) gene promoter polymorphisms in patients with chronic periodontitis. J Clin Periodontol 2005;32:207-11

10. Rail B, Kharb S, Jain R, Anand SC. Biomarkers of periodontitis in oral fluids. J Oral Science 2008;50:53-6.

11. Chang Y-C, Lai CC, Yang SF, Chan Y, Hsieh YS. Stimulation of matrix metalloproteinases by black-pigmented Bacteroides in human pulp and periodontal ligament cell cultures. J Endod 2002;28:90-3.

12. Pattamapun K, Tiranathanagul S, Yongchaitrakul T, Kuwatanasuchat $J$ Pavasant P. Activation of MMP-2 by Porphyromonas gingivalis in human periodontal ligament cells. J Periodontal Res 2003;38:115-21. 